\title{
Short communication: Effects of changing teatcup removal and vacuum settings on milking efficiency of an automatic milking system
}

\author{
J. Upton, ${ }^{1 *}$ P. Silva Bolona, ${ }^{2}$ and D. J. Reinemann ${ }^{3}$ \\ ${ }^{1}$ Animal and Grassland Research and Innovation Centre, Teagasc Moorepark, Fermoy P61C996, Co. Cork, Ireland \\ ${ }^{2}$ Department of Dairy Science, University of Wisconsin, Madison 53706 \\ ${ }^{3}$ Biological Systems Engineering Department, University of Wisconsin, Madison 53706
}

\section{ABSTRACT}

The aim of this experiment was to assess strategies to reduce milking time in a pasture-based automatic milking system (AMS). Milking time is an important factor in automatic milking because any reductions in box time can facilitate more milkings per day and hence higher production levels per AMS. This study evaluated 2 end-of-milking criteria treatments (teatcup removal at $30 \%$ and $50 \%$ of average milk flowrate at the quarter-level), 2 milking system vacuum treatments (static and dynamic, where the milking system vacuum could change during the peak milk flowrate period), and the interaction of these treatment effects on milking time in a Lely Astronaut A4 AMS (Maassluis, the Netherlands). The experiment was carried out at the research facility at Teagasc Moorepark, Cork, Ireland, and used 77 spring-calved cows, which were managed on a grass-based system. Cows were 179 DIM, with an average parity of 3 . No significant differences in milk flowrate, milk yield, box time, milking time, or milking interval were found between treatments in this study on cows milked in an AMS on a pasture-based system. Average and peak milk flowrates of $2.15 \mathrm{~kg} / \mathrm{min}$ and $3.48 \mathrm{~kg} / \mathrm{min}$, respectively, were observed during the experiment. Small increases in maximum milk flowrate were detected $(+0.09 \mathrm{~kg} / \mathrm{min})$ due to the effect of increasing the system vacuum during the peak milk flow period. These small increases in maximum milk flowrate were not sufficient to deliver a significant reduction in milking time or box time. Furthermore, increasing the removal setting from $30 \%$ of the average milk flowrate to $50 \%$ of the average milk flowrate was not an effective means of reducing box time, because the resultant increase in removal flowrate of $0.12 \mathrm{~kg} / \mathrm{min}$ was not enough to deliver practical or statistically significant decreases in milking time or box time. Hence, to make

Received November 22, 2018.

Accepted June 30, 2019.

*Corresponding author: John.Upton@teagasc.ie significant reductions in milking time, where cows have an average milk flow of $2 \mathrm{~kg} / \mathrm{min}$ and yield per milking of $10 \mathrm{~kg}$, end-of-milking criteria above $50 \%$ of average milk flowrate at the quarter level would be required.

Key words: milking, removal settings, milking vacuum

\section{Short Communication}

The cluster-on time of individual cows is an important factor for determining herd milking times and, thus, labor efficiency in conventional milking systems. In the context of automatic milking systems (AMS), cluster-on time has a direct effect on cow box time and, hence, the number of milkings that are possible per day. It has been reported that the cluster-on time of cows can be reduced without affecting milk yield or udder health indicators, by increasing the automatic cluster remover (ACR) milk flowrate switch point (milk flow at which the teatcup is removed) at the udder level (Rasmussen, 1993; Stewart et al., 2002; Magliaro and Kensinger, 2005; Jago et al., 2010; Burke and Jago, 2011). A study by Edwards et al. (2013a) performed on dairy cows in late lactation reported that udder-level ACR milk flowrate switch points up to $0.8 \mathrm{~kg} / \mathrm{min}$ reduced individual cluster-on times without affecting milk yield or indicators of udder health when using a milking routine with no pre-milking stimulation, as is common practice on pasture-based dairy farms (Edwards et al., 2013a). Increasing ACR milk flowrate switch point had no effect on indicators of udder health, despite more residual milk due to earlier removal of the cluster (Burke and Jago, 2011; Edwards et al., 2013a). The presence of residual milk is thought by many farmers to be linked with mastitis. However, increasing evidence indicates that an increase in residual milk does not adversely affect SCC or rates of clinical mastitis (Clarke et al., 2008; Jago et al., 2010; Burke and Jago, 2011; Edwards et al., 2013b). However, this may only hold true up to a point, as Penry et al. (2017) found a slight increase in SCC $(26,300$ to 48,300 cells/mL) when approximately $30 \%$ of the milk was left in a half udder. Furthermore, 
Burke and Jago (2011) noted a $1 \%$ reduction in milk production (kilograms per day) as a result of applying a $0.4 \mathrm{~kg} / \mathrm{min}$ udder-level milk flowrate switch point compared with $0.2 \mathrm{~kg} / \mathrm{min}$. In addition Magliaro and Kensinger (2005) documented a $2.5 \%$ reduction in milk yield (kilograms per milking) for a $0.8 \mathrm{~kg} / \mathrm{min}$ udderlevel milk flowrate switch point when compared with a $0.48 \mathrm{~kg} / \mathrm{min}$ setting.

Many AMS have the ability to carry out teatcup removal at the quarter level. To address this topic Krawczel et al. (2017) carried out an experiment with teatcup removal milk flowrate switch points ranging from 0.06 to $0.48 \mathrm{~kg} / \mathrm{min}$ at the quarter level. The effect of changing teatcup removal milk flowrate switch point setting was significant, with the highest setting resulting in the lowest milking time. Milk yield, peak flowrate, or average flowrate were not significantly affected by milk flowrate switch point level (Krawczel et al., 2017).

Milking interval is an important factor in AMS because it affects the degree of udder fill and, hence, the quantity of milk to be harvested at a given milking (Bruckmaier and Hilger, 2001). The milking interval was maintained at $8 \mathrm{~h}$ in the studies of Ferneborg et al. (2016) and Krawczel et al. (2017). However, in seasonal pasture-based AMS farms, the milking interval is generally between 12 and $18 \mathrm{~h}$ depending on the stage of lactation and level of concentrate feed allocation (Shortall et al., 2018). Furthermore, not every AMS teatcup removal system works on the basis of specifying a milk flowrate switch point based on an absolute flowrate. Hence, further research is required to investigate the effects of different teatcup removal strategies (e.g., percent of average flowrate) on the milking times of cows.

In addition to offering the user adjustable removal settings, many AMS offer an option to adjust the system vacuum level, or to apply a vacuum level that depends on the milk flowrate. It is widely accepted that increasing vacuum levels increases the peak milk flowrate (Penry et al., 2018) and milking speed (Rasmussen and Madsen, 2000; Spencer et al., 2007; Penry et al., 2016). There is a gap in knowledge in the literature around the effects of varying the vacuum during the peak milk flowrate period on milking time and also around how these settings would affect the milking time across different removal settings in an AMS.

The aim of this experiment, therefore, was to measure the effect of adjusting the teatcup removal milk flowrate switch point (as a percentage of average quarter-level flowrate) on the milking time of cows, as well as the effect of varying the milking system vacuum during the peak milk flow period on different removal settings in a pasture-based AMS.
This experiment was carried out at the research facility at Teagasc Moorepark, Cork, Ireland. The research farm operated a spring-calving, grass-based system. Cows were milked using a single Astronaut A4 robotic milking system (Lely, Maassluis, the Netherlands). The AMS was equipped with the custom take-off (CTO) module that enabled adjustment of the teatcup removal milk flowrate switch point as well as the time delay of the teatcup removers from trigger flowrate level to removal of the teatcup from the teat. The AMS system vacuum level was set to $43 \mathrm{kPa}$, and the pulsation system operated on a pulsator ratio of $65: 35$, with 60 pulses per minute.

The treatments consisted of 2 teatcup milk flowrate switch point settings and 2 vacuum settings. Normal removal (NR) removed the teatcup from the teat when the instantaneous milk flowrate dropped below $30 \%$ of the average within-milking milk flowrate for that teat; early removal (ER) removed the teatcup when the instantaneous milk flowrate dropped below $50 \%$ of the average flowrate for that teat; normal vacuum (NV) maintained the default system vacuum of $43 \mathrm{kPa}$ for the entire milking; and dynamic vacuum (DV) increased the system vacuum level (from the default of $43 \mathrm{kPa}$ ) by $1 \mathrm{kPa}$ for each kilogram per minute of milk flowrate over $2 \mathrm{~kg} / \mathrm{min}$. Hence, the 4 treatments were described as (1) normal removal with normal vacuum, NRNV; (2) early removal with normal vacuum, ERNV; (3) normal removal with dynamic vacuum, NRDV; and (4) early removal with dynamic vacuum, ERDV. The time delay from the quarter flowrate reaching the milk flowrate switch point and removal of the teatcup was set to $3 \mathrm{~s}$.

Cows were sorted into 4 groups and transitioned through the 4 treatments in a $2 \times 2$ factorial design. The treatments were applied in 4 experimental periods of $3 \mathrm{~d}$ each, with a 2-d washout period (during which the cows were milked with NRNV) between experimental periods. The washout days were put in place to eliminate carryover effects between treatment periods. The NRNV treatment was used to milk the cows during the week before the experiment start date. Treatment application began on Aug. 8, 2017. The treatment period was selected assuming that the effect of the teatcup removal setting would be noticeable immediately after the treatment was applied, similar to what was implemented in cognate studies by Edwards et al. (2013b; 2-wk treatment periods) and Krawczel et al. (2017; 7-d treatment period).

Cows were suitable for enrolment in the study provided that they had not presented with a clinical case of mastitis during the 2017 milking season (milking season for spring calving is typically February to No- 
vember) and that they had an udder-level SCC less than 200,000 cells $/ \mathrm{mL}$ at a milk recoding test carried out $3 \mathrm{~d}$ before implementation of the first experimental treatment period. All cows selected had 4 functional milking quarters. Milk samples were collected using the Shuttle (Lely), and SCC was measured using a Fossomatic machine (Foss Analytics, Hillerød, Denmark). Milk samples were treated in the Shuttle using broadspectrum microtabs (Advanced Instruments Inc., Norwood, MA) in each milk sampling bottle, to preserve the samples until they were transported to the milk testing laboratory.

A total of 77 cows were enrolled in the experiment: 68 Holstein Friesians, 7 Jerseys, and 2 Norwegian Reds. Cows were 179 DIM (range 110 to 234 DIM) and had an average parity of 3 (range 1 to 7 ). Average milking interval was $14.2 \mathrm{~h}$ (range 7.3 to $24.5 \mathrm{~h}$ ). Milk production per milking was $9.6 \mathrm{~L}$ per cow (range 2.2 to 24.8 L). Cows were blocked by breed (Holstein Friesian or Other, which included Jerseys and Norwegian Reds), parity $(1$ or $>1)$, and maximum milk flowrate $(<3.5$ or $\geq 3.5 \mathrm{~kg} / \mathrm{min}$ ), and randomly assigned to the 4 treatment groups.

Each cow was milked on average 1.7 times per day, which resulted in 1570 raw data points (5.1 milkings per cow per treatment) per variable over the course of the experiment. Data reports were combined from the AMS and the milk testing laboratory using spreadsheets. Data were manipulated and filtered in SAS 9.4 (SAS Institute Inc., Cary, NC). Prior to processing, box times greater than 15 min were removed, and milk yields of less than $1.5 \mathrm{~kg}$ per milking were removed. These steps removed $4 \%$ of raw data points. The following mixed model procedure (Proc GLMIX) was used to assess whether the dependent variable ( $y$ in Equation [1]) was influenced by the treatments:

$$
y=\text { Treatment }+ \text { Block, }
$$

where $y=$ milking time (duration of milk flow, in seconds), box time (period that the cow was present in the AMS, in seconds), average udder-level milk flowrate (kilograms per minute), maximum udder-level milk flowrate (kilograms per minute), milk yield per milking (kilograms), or milking interval (hours). Treatment (NRNV, NREV, ERNV, or ERDV), block (1 to 8), and cow identification number (CowID) were chosen as class variables. We declared CowID as a random variable and a repeated measure with an auto-regressive covariance structure, $\operatorname{AR}(1)$.

A similar model structure was used to determine the effect of vacuum and removal settings independently. The following mixed model procedure (Proc GLMIX) was used to assess whether the dependent variable $(y$ in Equation [2]) was influenced by the treatments:

$$
\begin{gathered}
y=\text { Removal }+ \text { Vacuum }+ \text { Removal } \\
\times \text { Vacuum }+ \text { Block },
\end{gathered}
$$

where $y=$ milking time (in seconds), box time (in seconds), average udder-level milk flowrate (kilograms per minute), maximum udder-level milk flowrate (kilograms per minute), milk yield per milking (kilograms), or milking interval (hours). Removal (NR or ER), vacuum (NV or DV), block (1 to 8), and CowID were chosen as class variables. We declared CowID as a random variable and a repeated measure with an auto-regressive covariance structure, AR(1). Differences between treatments with $P<0.05$ were declared significant.

Table 1 shows the least squares means (LSM) for 6 key milking efficiency variables for each treatment, generated using the model described in Equation [1]. The main effect of treatment on average milk flowrate, milk yield, box time, milking time, and milking interval was not significant; $P$-values are displayed in Table 1 . The effect of treatment on maximum milk flowrate was sig-

\begin{tabular}{|c|c|c|c|c|c|c|}
\hline \multirow[b]{2}{*}{ Variable } & \multicolumn{4}{|c|}{ Treatment $^{1}$} & \multirow[b]{2}{*}{ SEM } & \multirow[b]{2}{*}{$P$-value } \\
\hline & NRNV & NRDV & ERNV & ERDV & & \\
\hline Average milk flowrate $(\mathrm{kg} / \mathrm{min})$ & $2.04^{\mathrm{a}}$ & $2.04^{\mathrm{a}}$ & $2.00^{\mathrm{a}}$ & $2.06^{\mathrm{a}}$ & 0.07 & 0.38 \\
\hline Maximum milk flowrate $(\mathrm{kg} / \mathrm{min})$ & $3.25^{\mathrm{ab}}$ & $3.33^{\mathrm{a}}$ & $3.18^{\mathrm{b}}$ & $3.28^{\mathrm{ab}}$ & 0.10 & 0.04 \\
\hline Milk yield (kg) & $9.58^{\mathrm{a}}$ & $9.56^{\mathrm{a}}$ & $9.39^{\mathrm{a}}$ & $9.72^{\mathrm{a}}$ & 0.31 & 0.56 \\
\hline Box time $(\mathrm{s})$ & $390^{\mathrm{a}}$ & $391^{\mathrm{a}}$ & $390^{\mathrm{a}}$ & $391^{\mathrm{a}}$ & 13 & 0.10 \\
\hline Milking time (s) & $316^{\mathrm{a}}$ & $315^{\mathrm{a}}$ & $313^{\mathrm{a}}$ & $317^{\mathrm{a}}$ & 13 & 0.90 \\
\hline Milking interval (h) & $14.28^{\mathrm{a}}$ & $14.38^{\mathrm{a}}$ & $13.91^{\mathrm{a}}$ & $14.25^{\mathrm{a}}$ & 0.30 & 0.47 \\
\hline
\end{tabular}
nificant $(P=0.04)$. Treatment NRDV had a maximum

Table 1. Effect of treatment on 6 key milking efficiency variables; $P$-values indicate significance of treatment on each variable

${ }^{\mathrm{a}, \mathrm{b}}$ Variables with different superscript letters within rows differ significantly at the $P<0.05$ level.

${ }^{1} \mathrm{NRNV}=$ normal removal with normal vacuum; NRDV = normal removal with dynamic vacuum; ERNV $=$ early removal with normal vacuum; $\mathrm{ERDV}=$ early removal with dynamic vacuum. 
Table 2. Effect of removal milk flowrate switch point setting and vacuum setting on 6 key milking efficiency variables; $P$-values indicate significance of removal setting or vacuum setting on each variable

\begin{tabular}{|c|c|c|c|c|c|c|c|c|}
\hline \multirow[b]{2}{*}{ Treatment } & \multicolumn{3}{|c|}{ Removal $^{1}$} & \multirow[b]{2}{*}{$P$-value } & \multicolumn{3}{|c|}{ Vacuum $^{2}$} & \multirow[b]{2}{*}{$P$-value } \\
\hline & Normal & Early & SEM & & Normal & Dynamic & SEM & \\
\hline Maximum milk flowrate $(\mathrm{kg} / \mathrm{min})$ & 3.29 & 3.23 & 0.09 & 0.20 & 3.22 & 3.30 & 0.09 & 0.01 \\
\hline Milk yield (kg) & 9.57 & 9.56 & 0.29 & 0.92 & 9.49 & 9.64 & 0.29 & 0.31 \\
\hline Box time $(\mathrm{s})$ & 391 & 391 & 13 & 0.93 & 390 & 391 & 13 & 0.85 \\
\hline Milking time (s) & 316 & 315 & 13 & 0.91 & 315 & 316 & 13 & 0.72 \\
\hline
\end{tabular}

${ }^{1}$ Normal removal removed the teatcup from the teat when the instantaneous milk flowrate dropped below $30 \%$ of the average within-milking milk flowrate for that teat. Early removal removed the teatcup when the instantaneous milk flowrate dropped below $50 \%$ of the average flowrate for that teat.

${ }^{2}$ Normal vacuum level maintained the default system vacuum level of $43 \mathrm{kPa}$ for the entire milking. Dynamic vacuum increased the system vacuum level from the default (43 kPa) by $1 \mathrm{kPa}$ for each kilogram per minute of milk flowrate over $2 \mathrm{~kg} / \mathrm{min}$.

milk flowrate of $3.33 \mathrm{~kg} / \mathrm{min}$, which was $5 \%$ larger than the lowest maximum milk flowrate of treatment ERNV.

Table 2 shows the LSM for 6 key milking efficiency variables for each level of removal setting (NR or ER) and for each level of vacuum setting (NV or DV). These LSM were generated using the model described in Equation [2]. The interactive effect of removal $x$ vacuum was not significant $(P>0.8)$ for any of the dependent variables and was removed from the final model. The effect of removal setting on average milk flowrate, maximum milk flowrate, milk yield, box time, milking time, and milking interval was not significant; $P$-values are displayed in Table 2 .

The effect of vacuum setting on average milk flowrate, milk yield, box time, milking time, and milking interval was not significant; $P$-values are displayed in Table 2 . The effect of vacuum setting on maximum milk flowrate was significant $(P=0.01)$. The DV setting had a maximum milk flowrate of $3.30 \mathrm{~kg} / \mathrm{min}$, which was $2.5 \%$ larger than the maximum milk flowrate of the normal vacuum setting.

Table 3 indicates that an increase in system vacuum was applied at $93 \%$ of milkings that were assigned to the DV setting; that is, $93 \%$ of milkings exceeded a maximum udder-level milk flowrate of $2 \mathrm{~kg} / \mathrm{min}$ and, hence, experienced a system-level vacuum increase of at least $1 \mathrm{kPa}$. An increase of $2 \mathrm{kPa}$ in system vacuum was applied in $64 \%$ of milkings, a $3-\mathrm{kPa}$ increase in $34 \%$ of milking, a $4-\mathrm{kPa}$ increase in $12 \%$ of milkings, and a 5 - $\mathrm{kPa}$ increase in $1 \%$ of milkings.

The extent to which the DV treatment influenced milking time in this study depended on the length of time that the flowrate remained above the milk flowrate switch point of $2 \mathrm{~kg} / \mathrm{min}$ and, hence, the length of time during each milking that the DV setting was applied. Thus, for herds with longer and higher peak milk flowrates, a larger effect due to the DV setting might be expected. To understand how this DV set- ting functioned in more detail in this study, flow profile data would be required at each milking. However, this information was not available from the AMS used in this study.

The relatively low average udder-level $(2.16 \mathrm{~kg} / \mathrm{min})$ and quarter-level $(0.74 \mathrm{~kg} / \mathrm{min})$ milk flowrates observed help to explain the lack of a treatment effect on the key milking efficiency variables. The average flowrate of all milkings on the ER setting $(0.75 \mathrm{~kg} / \mathrm{min})$ was just 0.01 $\mathrm{kg} / \mathrm{min}$ higher than that of the NR setting $(0.75 \mathrm{~kg} /$ min). This is likely because the average quarter-level teatcup removal flowrate was just $0.15 \mathrm{~kg} / \mathrm{min}$ higher on the ER setting $(0.37 \mathrm{~kg} / \mathrm{min})$ versus the NR setting $(0.22 \mathrm{~kg} / \mathrm{min})$. These flowrates were determined by the AMS, as a product of the percentage of average flowrate-based removal logic. The underlying reason for these low removal milk flowrate switch points may be due to the modus operandi of the removal logic. Where the milk flowrate profile of a cow drops rapidly from a high peak flowrate period, one would expect to see a larger difference between a $30 \%$ of average flowrate removal setting versus a $50 \%$ of average flowrate removal

Table 3. Distribution of milkings on the dynamic vacuum (DV) setting: a total of 747 milkings were carried out on the DV setting; system vacuum level increased by $1 \mathrm{kPa}$ for every $1 \mathrm{~kg} / \mathrm{min}$ of milk flowrate over $2 \mathrm{~kg} / \mathrm{min}^{1}$

\begin{tabular}{lccc}
\hline $\begin{array}{l}\text { Maximum milk } \\
\text { flowrate }(\mathrm{kg} / \mathrm{min})\end{array}$ & $\begin{array}{c}\text { Milkings } \\
\text { (no.) }\end{array}$ & $\begin{array}{c}\text { Milkings } \\
(\%)\end{array}$ & $\begin{array}{c}\text { Maximum } \\
\mathrm{kPa}\end{array}$ \\
\hline$<2$ & 49 & 7 & 43 \\
$\geq 2$ & 698 & 93 & 44 \\
$\geq 3$ & 475 & 64 & 45 \\
$\geq 4$ & 256 & 34 & 46 \\
$\geq 5$ & 86 & 12 & 47 \\
$\geq 6$ & 6 & 1 & 48 \\
$\geq 7.0$ & 2 & 0 & 49
\end{tabular}

${ }^{1}$ It is not known how long the flowrate remained above $2 \mathrm{~kg} / \mathrm{min}$ at each milking, due to lack of milk flowrate profiles from the AMS utilized in this study. 
setting; however, where cows have a relatively low average udder level milk flowrate of approximately $2 \mathrm{~kg} / \mathrm{min}$ (see Table 1), the difference between the settings is not large enough to shorten box time. Milk ejection profiles with a high peak milk flow period and rapid declining phases were reported by Bruckmaier and Hilger (2001). Furthermore, the declining flow phase was elongated at lactation wk 37 compared with wk 6 (Bruckmaier and Hilger, 2001). This elongated declining phase would have the effect of reducing the average milk flowrate and depressing the quarter teatcup removal flowrates where the removal level was calculated as a percentage of the average milk flowrate. Furthermore, the AMS used in this study had a hard-coded maximum quarterlevel milk flowrate limit of $0.5 \mathrm{~kg} / \mathrm{min}$, as described by Silva Boloña et al. (in press). This $0.5 \mathrm{~kg} / \mathrm{min}$ threshold would not have interfered with any of the milkings on the normal milk flow switch point setting; however, we estimate that $13 \%$ of milkings on the early milk flowrate switch point setting would have been affected by the $0.5 \mathrm{~kg} / \mathrm{min}$ limit. This limit may have been a contributing factor in our inability to detect significant differences in box time across treatments.

The study performed by Krawczel et al. (2017) reported quarter-level average milk flowrates ranging between 0.90 and $0.97 \mathrm{~kg} / \mathrm{min}$ and detected a significant difference in milking time with teatcup removal milk flowrate switch points ranging from 0.06 to $0.48 \mathrm{~kg} /$ min. The average quarter-level flowrates observed in this study ranged from 0.73 to $0.76 \mathrm{~kg} / \mathrm{min}$, higher than those reported by Tančin et al. (2006; $0.62 \pm 0.02 \mathrm{~kg} /$ min, \pm SEM, in the sixth month of lactation), suggesting that the quarter flowrates of the cows in the present study were not unusually low. Although the quarter flowrates observed in our study were within the range reported in the literature, it is important to interpret the results with caution. Higher-yielding cows (such as those housed indoors and fed a TMR), with higher average quarter yields and flowrates, may have a different response to the treatments applied in this study. To make significant reductions in milking time, where cows have an average milk flow of approximately $2 \mathrm{~kg} /$ min and yield per milking of approximately $10 \mathrm{~kg}$, and where the end of milking is determined by a percentage of average milk flow rate, end-of-milking criteria above $50 \%$ of average milk flow rate at the quarter level would be required.

The average interval between milkings in this study was $14.2 \mathrm{~h}$ (1.7 milkings per day), which differs from other studies, where cows were milked much more frequently - for instance, an interval of 6.7 to $7.8 \mathrm{~h}$ in the study of Krawczel et al. (2017). Hence, results from teatcup removal studies with milking intervals of greater than twice per day should be interpreted with caution in the context of pasture-based AMS farms where milking intervals tend to drop below twice per day.

In summary, no significant differences in the milking efficiency variables of milk flowrate, milk yield, box time, milking time, and milking interval were found between treatments in this study on cows milked in an AMS on a pasture-based system. Small increases in maximum milk flowrate were detected (increase of 0.09 $\mathrm{kg} / \mathrm{min}$ ), due to the effect of increasing the vacuum when the milk flowrate increased beyond the udderlevel milk flowrate switch point of $2 \mathrm{~kg} / \mathrm{min}$.

\section{ACKNOWLEDGMENTS}

The authors gratefully acknowledge the support of the Teagasc Wash Fellowship Programme (Carlow, Ireland), the University of Wisconsin-Madison, and Lely (Maassluis, the Netherlands). We acknowledge the technical assistance of the staff at the Dairygold research farm at Teagasc Moorepark (Cork, Ireland) and the staff at Lely in the operation of the experiment. We acknowledge Peter Crump at the Statistical Consulting Group in the College of Agricultural and Life Sciences (University of Wisconsin-Madison) for statistical advice.

\section{REFERENCES}

Bruckmaier, R. M., and M. Hilger. 2001. Milk ejection in dairy cows at different degrees of udder filling. J. Dairy Res. 68:369-376.

Burke, J. K., and J. G. Jago. 2011. Comparing somatic cell counts, production and milking durations of dairy cows when milked at two automatic cup-removal flow-rate thresholds. Anim. Prod. Sci. 51:920-924.

Clarke, T., E. M. Cuthbertson, R. K. Greenall, M. C. Hannah, and D. Shoesmith. 2008. Incomplete milking has no detectable effect on somatic cell count but increased cell count appears to increase strip yield. J. Exp. Agric. 48:1161-1167.

Edwards, J. P., J. G. Jago, and N. Lopez-Villalobos. 2013a. Milking efficiency for grazing dairy cows can be improved by increasing automatic cluster remover thresholds without applying premilking stimulation. J. Dairy Sci. 96:3766-3773.

Edwards, J. P., J. G. Jago, and N. Lopez-Villalobos. 2013b. Shortterm application of prestimulation and increased automatic cluster remover threshold affect milking characteristics of grazing dairy cows in late lactation. J. Dairy Sci. 96:1886-1893.

Ferneborg, S., L. Stadtmüller, J. Pickova, L. Wiking, and K. Svennersten-Sjaunja. 2016. Effects of automatic cluster removal and feeding during milking on milking efficiency, milk yield and milk fat quality. J. Dairy Res. 83:180-187. https://doi.org/10.1017/ S0022029916000170.

Jago, J. G., J. L. Burke, and J. H. Williamson. 2010. Effect of automatic cluster remover settings on production, udder health, and milking duration. J. Dairy Sci. 93:2541-2549.

Krawczel, P., S. Ferneborg, L. Wiking, T. K. Dalsgaard, S. Gregersen, R. Black, T. Larsen, S. Agenäs, K. Svennersten-Sjaunja, and E. Ternman. 2017. Milking time and risk of over-milking can be decreased with early teat cup removal based on udder quarter milk flow without loss in milk yield. J. Dairy Sci. 100:6640-6647. 
Magliaro, A. L., and R. S. Kensinger. 2005. Automatic cluster remover setting affects milk yield and machine-on time in dairy cows. J. Dairy Sci. 88:148-153.

Penry, J. F., E. L. Endres, B. de Bruijn, A. Kleinhans, P. M. Crump, D. J. Reinemann, and L. L. Hernandez. 2017. Effect of incomplete milking on milk production rate and composition with 2 daily milkings. J. Dairy Sci. 100:1535-1540.

Penry, J. F., S. Leonardi, J. Upton, P. D. Thompson, and D. J. Reinemann. 2016. Assessing liner performance using on-farm milk meters. J. Dairy Sci. 99:6609-6618.

Penry, J. F., J. Upton, S. Leonardi, P. D. Thompson, and D. J. Reinemann. 2018. A method for assessing liner performance during the peak milk flow period. J. Dairy Sci. 101:649-660.

Rasmussen, M. D. 1993. Influence of switch level of automatic cluster removers on milking performance and udder health. J. Dairy Res. 60:287-297.

Rasmussen, M. D., and N. P. Madsen. 2000. Effects of milkline vacuum, pulsator airline vacuum, and cluster weight on milk yield, teat condition, and udder health. J. Dairy Sci. 83:77-84.
Shortall, J., C. Foley, R. D. Sleator, and B. O'Brien. 2018. The effect of concentrate supplementation on milk production and cow traffic in early and late lactation in a pasture-based automatic milking system. Animal 12:853-863.

Silva Boloña, P., D. J. Reinemann, and J. Upton. In press. Effect of teatcup removal settings on milking efficiency and milk quality in a pasture based automatic milking system. J. Dairy Sci.

Spencer, S. B., J. W. Shin, G. W. Rogers, and J. B. Cooper. 2007. Short communication: Effect of vacuum and ratio on the performance of a monoblock silicone milking liner. J. Dairy Sci. 90:17251728 .

Stewart, S., S. Godden, P. Rapnicki, D. Reid, A. Johnson, and S. Eicker. 2002. Effects of automatic cluster remover settings on average milking duration, milk flow, and milk yield. J. Dairy Sci. $85: 818-823$.

Tančin, V., B. Ipema, P. Hogewerf, and J. Mačuhová. 2006. Sources of variation in milk flow characteristics at udder and quarter levels. J. Dairy Sci. 89:978-988. 